\title{
Article \\ Financial flexibility, dynamic capabilities, and the performance of manufacturing enterprises
}

\author{
Jiangnan $\mathrm{Yi}{ }^{1 *}$ \\ 1 School of Management and Economics, Beijing Institute of Technology, Beijing, P.R. China; \\ yjn1949@163.com \\ * Correspondence: yjn1949@163.com; Tel.: +86 18801313163
}

Received: 5 February 2020; Accepted: 30 March 2020; Published: 4 April 2020

\begin{abstract}
This study explores the mechanism of financial flexibility on enterprise performance from the perspective of dynamic capabilities by testing the relationship among them respectively. This study selects the data of A-share manufacturing companies in Shenzhen and Shanghai from 2011 to 2017 to structure three main variables mentioned above. The test results of the regression analysis indicate that financial flexibility has an interval effect on enterprise performance. Dynamic capabilities play a part in mediating financial flexibility and enterprise performance, which means financial flexibility can influence enterprise performance through dynamic capabilities. This study adds weight to the theory of financial flexibility and dynamic capability and helps enterprises adjust them more effectively in an increasingly complex economic situation.
\end{abstract}

Keywords: financial flexibility; dynamic capability; enterprise performance; Chinese manufacturing enterprises

JEL codes: A11; B26; M11.

\section{Introduction}

Faced with an uncertain external environment, financial flexibility plays an important role in enterprises' strategic adjustment (Hayward, Caldwell, \& Steen, 2017). Financial flexibility refers to the ability of an enterprise to acquire or invoke resources timely, seize opportunities to invest and maximize its value (Graham \& Harvey, 2001; Byoun, 2011). Financial flexibility plays a role by invoking and raising financial resources and reconfiguring enterprise resources. It reveals dynamic characteristics and contingency. During the 2008 Global Financial Crisis, some enterprises survived bankruptcy, and in contrast to those which collapsed, they seized opportunities to obtain huge profits by acquiring other enterprises that were on the verge of bankruptcy (Zeng, Zhang, \& Wei, 2013). However, most of the existing researches emphasize the impact of financial flexibility on enterprise performance from the perspective of financing constraints, while paying little attention to dynamic capabilities. This aspect wasn't included in this mechanism. Dynamic capabilities indeed help enterprises obtain a sustainable and competitive advantage in an uncertain environment (Teece, Pisano, \& Schuen, 1997). Dynamic capabilities help business managers match organizational structures to rapidly changing external environments. This has been done by constant integration, construction and even refactoring enterprises' capabilities as environmental conditions change. The dynamic capability theory is an important theoretical basis for financial flexibility.

Under the backdrop of constant adjustments to economic policies, escalation of international trade disputes, and complex and ever-changing business environment, financial flexibility and dynamic capabilities have become the focus of academic research and a problem tough to be solved among enterprises. To have a strong industrial base, China needs to raise manufacturing enterprises to a new level to uphold the cornerstone of its economy. In line with this, the implementation of the "Made in 
China 2025" policy, many manufacturing enterprises have built competitive advantages and adapted to the changing environment by improving their financial flexibility and dynamic capabilities. Therefore, based on manufacturing listed companies in Shanghai and Shenzhen Securities Markets in China from 2011 to 2017, this article explores the relationship between financial flexibility and Manufacturing enterprise performance from the view of dynamic capabilities, with the expectancy to help business managers make more effective financial decisions in a dynamic environment.

This article makes three distinct contributions. First, through the mediation-effect test, the nature of the impact of financial flexibility on enterprise performance and its role path are clarified while also confirming the intermediary role that dynamic capabilities play between financial flexibility and enterprise performance. Second, this article integrates financial flexibility, dynamic capabilities, and enterprise performance into a theoretical framework and adds the relationship between financial flexibility and dynamic capabilities to the influencing factors of enterprise performance. This enriches the research of factors that affect enterprise performance. Third, this study introduces dynamic capabilities into the research framework, which can help enterprises adjust and manage financial flexibility and dynamic capabilities efficiently in a practice way. The benefit for them would be to gain advantages in the fiercely competitive market, further expanding the theory of financial flexibility and dynamic capability.

The remainder of the article is organized as follows: Section 2 shows the background of China's manufacturing industry. Section 3 reviews the literature and develops the theoretical framework and hypotheses. Section 4 describes a taken sample, variables, and corresponding measurement and Section 5 reports the regression test results. The final Section 6 offers conclusions drawn from the article and practical implications where relevant.

\section{Background}

Manufacturing is the cornerstone of modern industry. With the revolutionary breakthroughs and cross-integration of important fields, along with the forging ahead with change, such as information technology, new energy and new materials, a new round of industrial transformation is being triggered. In order to promote the development of intelligent manufacturing, China has released "Made in China 2025" to comprehensively promote the strategy that manufacturing can revitalize the country.

First, China's manufacturing value has significantly increased. Among the more than 500 major industrial products produced, more than 220 productions are ranked first in the world. In 2017, the added value of the manufacturing industry reached RMB 24,277 billion, an increase of over 300 times compared with the RMB 76 billion in 1970; an increase of 7 times compared with RMB 3,186.7 billion in 2000; compared with RMB 13,022.8 billion in 2010, more than doubling (Figure 1). In 2017, the value of manufacturing industry has already accounted for $29.34 \%$ of China's GDP.

Figure 1. China's manufacturing value added (1970-2017)

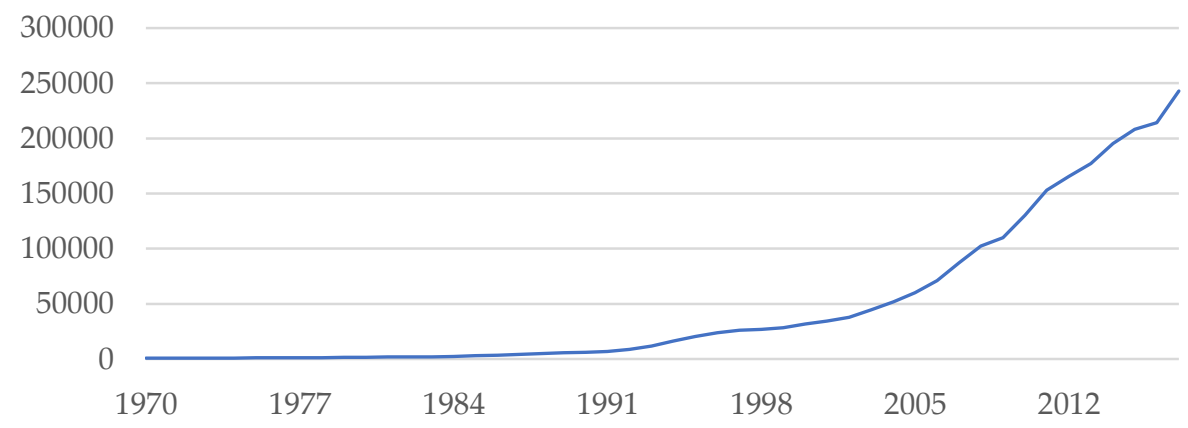

Data source: National Statistical Office' China Statistical Yearbook (1970-2017). The values are expressed in hundred million Yuan. 
Second, China's manufacturing industry is widely distributed. According to the Listed companies' industry classification in the second quarter of 2019 promulgated by China Securities Regulatory Commission, such companies can be divided into 30 categories. As of July 2019, among the 2290 listed companies in the manufacturing industry, computer, communications, and other electronic equipment manufacturing companies accounted for the largest proportion, reaching $14.98 \%$, and the waste resource comprehensive utilization industry accounts for the least, only $0.26 \%$ of which there are only 6 companies. As shown in Figure 2.

Figure 2. China's manufacturing listed companies' industry distribution map (2019)

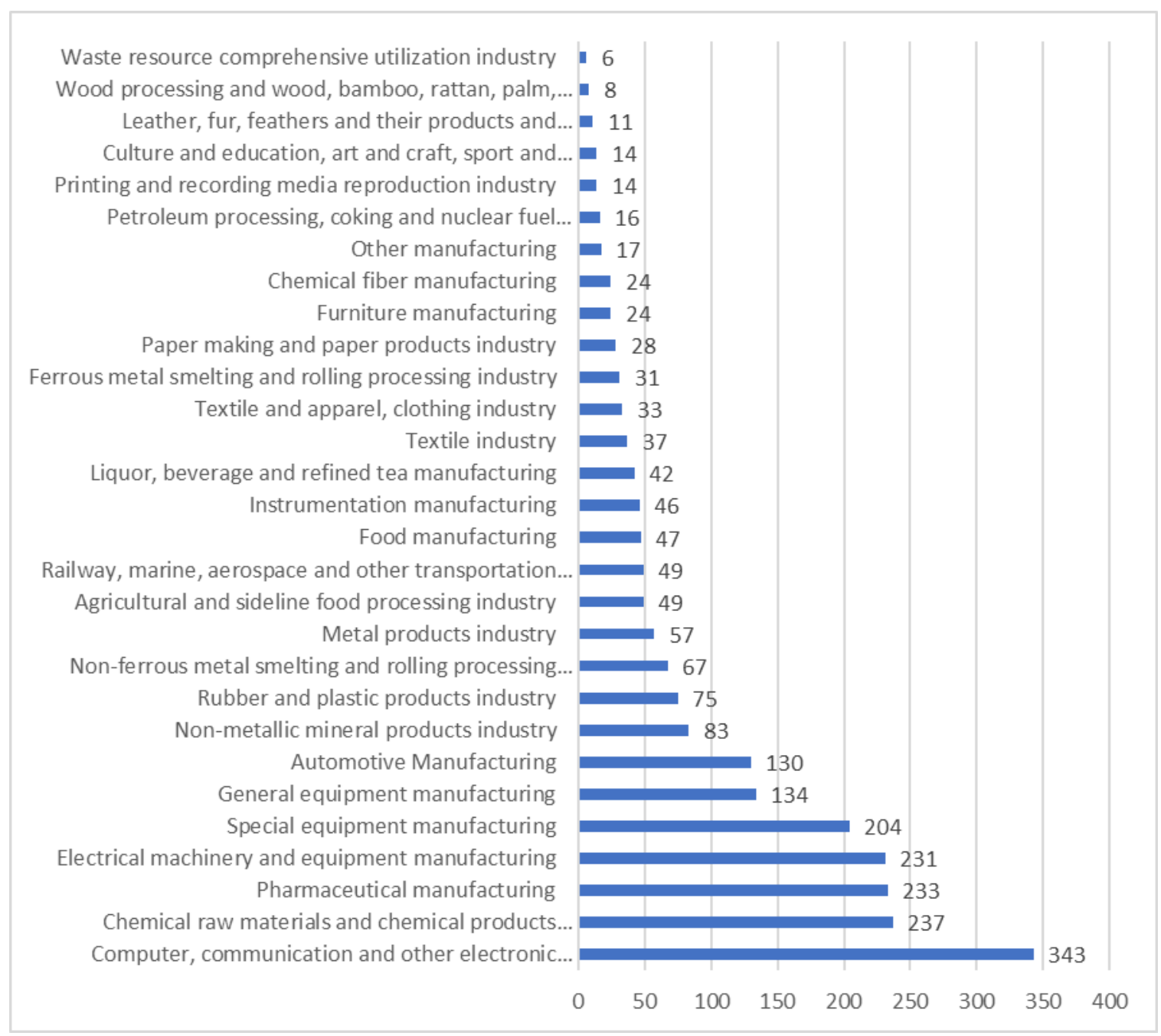

Data Source: China Securities Regulatory Commission (Listed company industry classification results in the second quarter of 2019), 2019-07-11.

Third, although the value-added of China's manufacturing industry has increased significantly, relevant indicators reflecting the financial flexibility and dynamic capabilities of enterprises, such as cash ratio, debt ratio, return on assets, and total asset turnover, are showing an unstable trend. As is shown in Figure 3, from 2000 through 2017, there was a great fluctuation in the industrial average of the cash ratio, debt ratio, return on assets and asset turnover of China's machinery manufacturing industry. The financial flexibility and dynamic capabilities of enterprises are important factors affecting the development of the manufacturing industry and are of great value to the research. 


\section{Literature Review and Hypothesis Development}

\subsection{Financial flexibility and enterprise performance}

The complex market of today that enterprises face necessitates greater risk-taking so businesses must increase their requirements for the allocation of financial resources. Financial flexibility creates the option for enterprises to cope with unpredictable investment and financing needs in the future, which makes up the core value of financial flexibility (YANG \& PAN, 2019). Early scholars mainly emphasized the "prevention" attribute of financial flexibility and considered that financial flexibility refers to the ability to respond to environmental changes through fund management (Gilson, Stuart, Warner, \& Jerold, 1998). Differently, Later scholars emphasized the "utilization" attribute of financial flexibility and believed that financial flexibility refers to the ability to obtain funds and adjust the resource structure to promote enterprise value (Arbogast, Stephen, Kumar, \& Praveen, 2018). Financial flexibility is a sort of strategic assets of enterprises. Through raising funds at low cost, enterprises can improve the efficiency of capital structure adjustment, meet investment needs, avoid financial distress, and strengthen the ability of enterprises to adapt to internal and external environmental changes and accidental shocks (Zeng et al., 2013). With the gradual increase of financial flexibility, the ability of enterprises to resist external shocks is enhanced. Meanwhile, they can raise funds with less time and seize the opportunities to invest, thereby promoting enterprise value. Some studies suggest that high financial flexibility has a positive effect on enterprise performance (Rapp, Schmid, \& Urban, 2014). Enterprises with high financial flexibility tend to perform better in a financial crisis (ArslanAyaydin, Florackis, \& Ozkan, 2014) since high financial flexibility helps enterprises make valuable investments during the crisis, it is also conducive to the optimal allocation of financial resources and control of financial risks (Cherkasova, Kuzmin, \& Gadjah, 2018).

Figure 3. Part of the financial indicators of China's machinery manufacturing industries

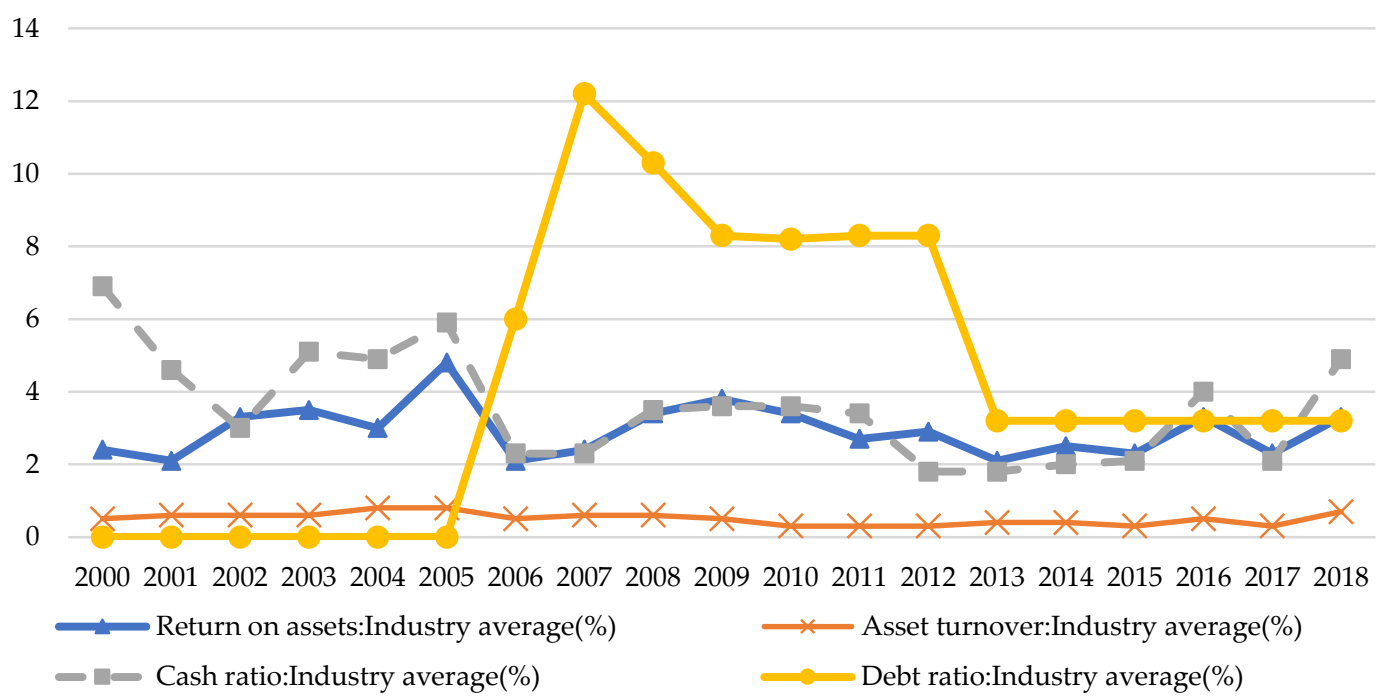

Data source: Huibo Investment Research Economic Database EDB

However, financial flexibility has an interval effect on enterprise performance. It has both positive and negative effects from a different perspective. From the perspective of financing constraints, low financial flexibility leads to insufficient investment (DONG \& MAO, 2016). From the perspective of agency costs, high financial flexibility can trigger excessive investment (Agha \& Faff, 2014). Both indicate that financial flexibility can, therefore, harm enterprise performance. The substantial cash reserves of enterprises are mainly used for prevention and utilization challenges. Excessive cash can 
cause corporate funds to be idle, while idle resources can cause an increase in opportunity costs. Simultaneously, because of the asymmetry of information, the management seeks to maximize their interests, so they can use idle funds for business plans that deviate from the shareholders' target but can increase their income, which adds to the agency cost of the enterprise (Jensen, 1986). And this hurts business performance. Existing studies have shown that debt has a governance effect, which can effectively constrain the excessive investment of enterprises and control managers' misconduct (Hart \& Moore, 1998).

An increase in financial flexibility means that the governance effect of enterprises' liabilities will be suppressed, which will also influence enterprise performance negatively. As an important factor affecting the financial management of an enterprise, the effect of financial flexibility on enterprise performance depends on the comparative relationship between the cost of carrying and potential benefits. When the potential income is greater than the cost of carrying, the company will enhance the financial flexibility reserve to promote performance. However, when the potential revenue is less than carrying costs, further improvement of financial flexibility reduces enterprise performance. In line with the above discussion the following hypothesis is developed:

H1: The relationship between financial flexibility and corporate performance is inverted Ushaped.

\subsection{Financial flexibility and dynamic capability}

To explain how enterprises acquire and maintain competitive advantages in a dynamic environment, for the first time, Teece and Pisano (1994) proposed the concept of dynamic capabilities and defined it as the capability that allows the firm to create new products and processes and responds to the changing market. Later, Teece and Pisano (1997) further defined dynamic capabilities as "the firm's ability to integrate, build, and reconfigure internal and external competences to address rapidly changing environments." and viewed dynamic capabilities as an extension of corporate resource perspectives. Teece (2007) decomposed dynamic capabilities into three underlying dimensions: (1) to sense and shape opportunities and threats, (2) to seize opportunities, and (3) to maintain competitiveness through enhancing, combining, protecting, and, when necessary, reconfiguring the business enterprise's intangible and tangible assets. Dynamic capabilities are in the process of enterprise organization management, affecting management decisions and helping companies maintain competitive advantages in the changing market. Helfat et al. (2007) defined dynamic capabilities like the ability of an organization to purposefully create, extend, or modify its resource base, and pointed out that dynamic capabilities should include capabilities such as searching, selecting, and configuration. Barreto (2010) further divided dynamic capabilities into four dimensions: (1) to sense opportunities and threat tendencies, (2) to make timely decisions, (3) to make a marketoriented decision and (4) to change resource bases. Paul and Omar (2011) separated dynamic capabilities into the abilities to sense, to learn, to coordinate, and to integrate. Wilhelm, Schlömer and Maurer (2015) argued that dynamic capabilities should include three dimensions of sensing, learning, and reconfiguration. Sensing refers to identify relevant changes and opportunities. Learning refers to develop new ways of responding to observed environmental changes and opportunities. And reconfiguration refers to reorganizing existing operating routines. Existing research has made it an important part of defining dynamic capabilities that enterprises must adjust the original framework structure or resource allocation.

It is the purpose of enterprises reserving financial flexibility to address the changing external market, while the changing external market also makes it hard for enterprises to enhance their value by relying on existing capital structure and resource combination. Regularly, enterprises will maintain relatively low financial flexibility when the dynamic nature of the external market is low. At this time, the less organizational structure needs to be adjusted, consequently, the profits of upholding a certain level of dynamic capability are limited. However, dynamic capabilities also entail costs associated with devoting resources to change activities (Zollo \& Winter, 2002). In such an event, firms usually incur transaction and coordination costs when altering their resource base (Karim, 2006), with the result that 
the profits tend to suffer more so than the corresponding costs outlay. In a highly dynamic market condition where unstable factors cause complications, the financial flexibility of the enterprise is often at full stretch. Considering that dynamic capabilities proceed along a dependent path, matching inertia problems and other factors, can make dynamic capabilities difficult to adhere to.

Besides, the high cost of dealing with issues caused by maintaining strong dynamic capabilities can negatively impact enterprise performance to a certain extent (Teece, 2012). Eisenhard and Martin (2000) empirically demonstrated that dynamic capabilities exerted the strongest impact on enterprise competence in moderately dynamic environments. Fainshmidt et al. (2019) showed that dynamic capabilities provided a competitive advantage for enterprises in a dynamic environment by achieving a combination of differentiation and low cost. Thus, in a low or high dynamic external environment, considering the cost issue, the enterprise will not maintain a strong dynamic capability. Wang and Tang (2017) empirically proved that environmental uncertainty is significantly positively correlated with financial flexibility. However, according to the above discussion, the impact of environmental uncertainty on the dynamic capabilities of firms is not a simple linear relationship. Thus, we derive the following hypothesis:

H2: The relationship between financial flexibility and dynamic capabilities is inverted U-shaped.

\subsection{The mediating roles of dynamic capabilities}

Enterprises can adapt to environmental changes through resource restructuring, and bring competitive advantages to enterprises through dynamic capabilities. These can create new resource combinations that are difficult to be imitated (Griffith \& Harvey, 2001), and are considered as sources of excess economic rent (Makadok, 2001), which can lead to superior performance (Drnevich \& Kriauciunas, 2011). The value, specificity and difficulty of imitation of dynamic capabilities make it a source of sustainable competitive advantage for enterprises, which is conducive to improving performance. Drnevich and Kriauciunas (2011) researched a business process base and found that dynamic capabilities have a positive impact on both business and enterprise performance.

$\mathrm{Wu}$ (2006) found that from the inside, in an unstable environment, enterprise resources must influence the performance of enterprises through dynamic capabilities; Wang and Ahmed (2007) confirmed that dynamic capabilities are one of the pre-factors that affect enterprise performance. Again, in an uncertain external environment, through the flexible allocation of financial resources, this inner comprehensive regulatory capability affects non-financial factors such as market, technology, and organizational behavior. These non-financial factors reflect the ability of enterprises to grasp market opportunities, reconstruct and integrate resources, and the ability to innovate as well. Together, all these capabilities form the basis of a company's dynamic capabilities. Hence, the effect of financial flexibility on enterprise performance can be achieved by affecting the dynamic capabilities of enterprises. Thus, we derive the following hypothesis:

H3: Dynamic capabilities mediate the effect of financial flexibility on enterprise performance.

\section{Research Design}

\subsection{Data and samples}

Manufacturing is the mainstay of China's industrial transformation and upgrading, and the main driving force for China's economy to improve its quality and efficiency. Also, manufacturing plays a significant role in and receives great support from the central government in the Supply-side Structural Reform, which is among the most influential reforms in China in recent years. For example, plenty of Chinese manufacturing enterprises' taxes are cut down to encourage innovation. Therefore, In this study, all listed manufacturing enterprises in the A shares of the Shanghai and Shenzhen Stock Exchanges are used as initial samples to be screened according to the following criteria: ST, *ST company, the first year IPO company are excluded to avoid the impact of extreme data on the empirical results; from the year of 2011 when the sample data is missing less, the companies with more data missing during the sample period are eliminated. 
It was finally confirmed that 292 listed companies in the manufacturing industry were selected as research objects, and the period was selected from 2011 to 2017. To eliminate the influence of outliers, all continuous variable values are subjected to tailing processing by $1 \%$. The financial data of related enterprises are mainly from the CSMAR and WIND databases.

\subsection{Definitions of variables}

This article takes enterprise performance as the explanatory variable, financial flexibility as the main explanatory variable, and the dynamic ability of the firm as the mediator variable. These are the three key variables that constitute this paper.

\subsubsection{Financial flexibility}

Currently, financial flexibility is mainly measured through single-index, double-index, and multiindex comprehensive method. Considering China's special institutional background, which makes it difficult for enterprises to carry out equity financing, this article refers to the method used by Zeng et al. (2013). This article selected the dial indicator method and sets financial flexibility as

$(\mathrm{FF})=$ cash flexibility + debt flexibility

to assess the financial flexibility of enterprises from two aspects; i.e. that of cash holding and debt level. Among them,

cash flexibility $=$ corporate cash ratio - industry cash ratio,

debt flexibility $=\operatorname{Max}(0$, industry debt ratio - corporate debt ratio).

Also, this article uses relative indicators to measure the financial flexibility of an enterprise and objectively analyzes the impact of financial flexibility on dynamic capabilities and enterprise performance.

\subsubsection{Enterprise performance}

Enterprise performance refers to the enterprise's operating efficiency and performance in a certain period. The indicators for measuring micro-performance of enterprises are divided into two categories: namely subjective and objective. Taking account of the composition of financial flexibility indicators and the availability of data, the objective indicator (ROA) is selected for the master test in this article, which is defined as the ratio of interest-earnings before taxes to total assets. And the return on capital (ROC) is used for the robustness test.

\subsubsection{Dynamic capabilities}

Since dynamic capability is an abstract and highly generalized capability, most of the current academic measurement of dynamic ability is in the form of questionnaires and gives choices, while few scholars have proposed clear measurement indicators. This paper considers that dynamic capabilities are comprehensive capabilities including external opportunity perception, internal resource integration, and reconfiguration, along with transformation and innovation. Hence, the dynamic capability was measured under three sub-dimensions. Jose Ignacio and Angel ZunigaVicente, Jose (2003) used return on assets to measure the organizational capabilities of enterprises. The stronger the organizational capabilities of enterprises, the stronger their ability to integrate resources and reconfigure resources. On this basis, this article used return on assets as one of the indicators to scale this ability, which equals to the sum of total profit and financial expenses as a percentage of total assets. What is more, this article added asset turnover to scale it more exactly in that asset turnover can reflect the utilization efficiency of all assets, which is also a manifestation of the ability for enterprises to integrate and reconfigure resources. Zahra, Sapienza and Davidsson (2006) pointed out that managers' perceptions of threats and opportunities were critical to maintaining dynamic capabilities. Therefore, the average academic qualification of the board of directors is selected to reflect the ability of enterprise opportunity perception. Meanwhile, this paper selects the R\&D expenditure 
ratio to reflect the enterprises' level of transformation and innovation. Since the R\&D expenditure ratio is seriously missing, it is replaced by the ratio of intangible assets.

Since then, this study used the coefficient of variation method to determine the weights of four indicators mentioned above, to eliminate the influence of different dimensions of evaluation index and calculate the dynamic capacity objectively. The weights of the ratio of intangible assets, asset turnover, return on assets, and the average academic qualification of the board of directors of the listed companies in 2011-2017 are shown in Table 1. Take 2017 as an example, the dynamic capability of a listed company in manufacturing in $2017 \mathrm{DC}=0.278 \times \mathrm{X}_{1}+0.246 \times \mathrm{X}_{2}+0.422 \times \mathrm{X}_{3}+0.054 \times \mathrm{X}_{4}$. And so on, we can calculate the dynamic capacity of the sample manufacturing listed companies from 2011 to 2017. Detailed data are shown in Table 1.

Table 1. The weight of the measurement indicators from 2011 to 2017

\begin{tabular}{|c|c|c|c|c|c|c|c|}
\hline & 2011 & 2012 & 2013 & 2014 & 2015 & 2016 & 2017 \\
\hline $\begin{array}{l}\text { Ratio of intangible } \\
\text { assets }\end{array}$ & 0.331 & 0.322 & 0.316 & 0.368 & 0.307 & 0.305 & 0.278 \\
\hline Asset turnover & 0.257 & 0.236 & 0.243 & 0.242 & 0.234 & 0.256 & 0.246 \\
\hline Return on assets & 0.347 & 0.383 & 0.379 & 0.329 & 0.405 & 0.386 & 0.422 \\
\hline $\begin{array}{l}\text { Average academic } \\
\text { qualification of the } \\
\text { board of directors }\end{array}$ & 0.065 & 0.059 & 0.062 & 0.062 & 0.054 & 0.053 & 0.054 \\
\hline
\end{tabular}

Table 2. Definitions of variables

\begin{tabular}{|c|c|c|}
\hline $\begin{array}{c}\text { Variable } \\
\text { categories }\end{array}$ & $\begin{array}{l}\text { Variable } \\
\text { symbols }\end{array}$ & Measurement \\
\hline $\begin{array}{l}\text { Dependent } \\
\text { variable }\end{array}$ & ROA & $\begin{array}{l}\text { Enterprise performance, scaled by Earnings Before Interest and } \\
\text { Tax } \times 2 / \text { (opening asset }+ \text { closing asset }) \times 100 \%\end{array}$ \\
\hline $\begin{array}{l}\text { Mediating } \\
\text { variable }\end{array}$ & DA & $\begin{array}{l}\text { Dynamic capabilities, scaled by the standardization of Proportion of } \\
\text { intangible assets }(x 1) \text {, Return on assets }(x 2) \text {, Asset turnover }(x 3) \text { and } \\
\text { Average academic qualifications of the board of directors }(x 4)\end{array}$ \\
\hline \multirow{11}{*}{$\begin{array}{c}\text { Independent } \\
\text { variable } \\
\text { Control } \\
\text { variables }\end{array}$} & FF & Financial flexibility, scaled by sum of cash flexibility and debt flexibility \\
\hline & FF2 & Square of financial flexibility \\
\hline & Size & $\begin{array}{l}\text { Scaled by the natural logarithm of the total number of company } \\
\text { employees }\end{array}$ \\
\hline & Age & $\begin{array}{l}\text { Scaled by the minus of sample observation year and company } \\
\text { establishment year }\end{array}$ \\
\hline & Growth & $\begin{array}{l}\text { Scaled by the growth rate of gross sales in the current period compared } \\
\text { with the previous period }\end{array}$ \\
\hline & Top & $\begin{array}{l}\text { Scaled by the ratio of the total shares held by the top ten shareholders to } \\
\text { the total share capital }\end{array}$ \\
\hline & Owner & $\begin{array}{l}\text { Indicator variable equal to } 1 \text { if the enterprise is controlled by the state, } \\
\text { and } 0 \text { otherwise. }\end{array}$ \\
\hline & Dual & $\begin{array}{l}\text { Indicator variable equal to } 1 \text { if the chairman and general manager are } \\
\text { the same people, and } 0 \text { if not }\end{array}$ \\
\hline & Dsize & Number of the board of directors \\
\hline & Monisize & Number of the board of supervisors \\
\hline & TobinQ & The ratio of enterprise market value to capital replacement cost \\
\hline
\end{tabular}

Apart from this, other factors that may affect enterprise performance are selected as control variables, including enterprise size, age, growth, ownership, etc. Dummy variables are used to control the effects of time factors. Definitions and measurement of variables are shown in Table 2. 


\subsection{Empirical models}

To verify that financial flexibility affects dynamic capabilities and consequently affects corporate performance, this article follows the approach prescribed by Baron and Kenny (1986) and estimates the impact of financial flexibility and dynamic capabilities on enterprise performance, using ordinary least squares regressions. The mediating role of dynamic capability needs to meet the following conditions: First, the regression coefficient of FF to ROA in Eq.(1) is significant; Second, the regression coefficient of FF to DC Eq.(2) is significant; Third, in Eq.(3) the regression coefficient of DC to ROA is significant, while the regression coefficient of financial flexibility (FF) to ROA becomes smaller. When the regression coefficient of financial flexibility (FF) is not significant, it indicates that dynamic capability (DC) plays a full intermediary role; if not, it indicates that dynamic capability (DC) plays a partial intermediary role. Therefore, to test whether the hypothesis $\mathrm{H} 1, \mathrm{H} 2$, and $\mathrm{H} 3$ are established, three corresponding equations are created to verify the mediating role of dynamic capabilities in financial flexibility's performance effect.

$$
\begin{aligned}
& \mathrm{ROA}_{\mathrm{i}, \mathrm{t}}=\beta_{0}+\beta_{1} \mathrm{FF}_{\mathrm{i},-1}+\beta_{2} \mathrm{FF}_{\mathrm{i},-1}+\sum_{1} \mathrm{j} \delta_{\mathrm{j}} \text { Controls }_{\mathrm{i}, t}+\text { Yeardummy }+\varepsilon_{\mathrm{i}, \mathrm{t}} \\
& \mathrm{DC}_{\mathrm{i}, \mathrm{t}}=\beta_{0}+\beta_{1} \mathrm{FF}_{\mathrm{i},-\mathrm{-}-1}+\beta_{2} \mathrm{FF}_{\mathrm{i}, \mathrm{t}-12}+\sum \mathrm{i} \delta_{\mathrm{j}} \mathrm{Controls}_{\mathrm{i}, \mathrm{t}}+\text { Yeardummy }+\varepsilon_{\mathrm{i}, \mathrm{t}} \\
& \mathrm{ROA}_{\mathrm{i}, \mathrm{t}}=\beta_{0}+\beta_{1} \mathrm{DC}_{\mathrm{i}, \mathrm{t}}+\beta 2 \mathrm{FF}_{\mathrm{i}, \mathrm{-1}}+\beta_{3} \mathrm{FF}_{\mathrm{i}, \mathrm{t}-12}+\sum_{\mathrm{i}} \mathrm{i} \delta_{\mathrm{j}} \text { Controls }_{\mathrm{i}, \mathrm{t}}+\text { Yeardummy }+\varepsilon_{\mathrm{i}, \mathrm{t}}
\end{aligned}
$$

In the above models, $\mathrm{i}$ represents the company, $\mathrm{t}$ represents time, and $\Sigma 1 \mathrm{j} \delta \mathrm{j}$ Controls represents the sum of all control variables. Considering that financial flexibility has the nature of optionality and to eliminate two-way causal interference, the financial flexibility and its square term lag one phase in Eqs. (1), (2) and (3) and represented by $\mathrm{FF}_{\mathrm{i}, \mathrm{t}-1}$ and $\mathrm{FF}^{2} \mathrm{i}, \mathrm{t}-\mathrm{1}$. Ep.(1) estimates the impact of financial flexibility on enterprise performance and Ep.(2) estimates the impact of financial flexibility on dynamic capabilities, both using the square term of financial flexibility for regression analysis to determine whether the inverted U-shaped relationship is established. Last, Ep.(3) estimates the mediating role of dynamic capabilities in financial flexibility's enterprise performance effect.

\section{Empirical analysis}

\subsection{Descriptive statistics and correlation coefficient matrix}

Table 3 shows the descriptive statistical results and correlation coefficients of the variables. The following analysis is made according to the data. In the sample enterprises, the distribution of the profit level is skewed to the right, and the profit level of the sample companies varies greatly, but the overall has a certain degree of profitability. The overall distribution of sample enterprises' dynamic capabilities is not much different, and the distribution is relatively average. The financial flexibility of most sample enterprises is stronger than the average level, and the individual differences are large, indicating that the financial flexibility level of listed companies in China's manufacturing industry is unevenly distributed. However, the overall reserve has certain financial flexibility, and this may be related to the external environment in which China's current manufacturing enterprises are facing industrial transformation and upgrading.

Besides, the results in Table 3 show that financial flexibility is positively correlated with enterprise performance $(\beta=0.183, \mathrm{P}<0.001)$, and financial flexibility is negatively correlated with the dynamic ability $(\beta=-0.138, P<0.001)$. Yet their relationships still need to be further explored through regression analysis. Dynamic ability is positively correlated with corporate performance $(\beta=0.387, \mathrm{P}<0.001)$, indicating that the stronger the dynamic capability is, the better the enterprise performance will be. Also, the VIF values of the interpreted variables and the control variables are slightly greater than 1 , which means that there is no multicollinearity problem. 
Table 3. Descriptive statistics and correlations of model variables

\begin{tabular}{|c|c|c|c|c|c|c|c|c|c|c|c|c|}
\hline & ROA & DC & FF & Size & Age & Growth & Top & Owner & Dual & Dsize & Monisize & TobinQ \\
\hline (1)ROA & 1.000 & & & & & & & & & & & \\
\hline (2)DC & $0.387^{* * *}$ & 1.000 & & & & & & & & & & \\
\hline (3) FF & $0.183^{* * *}$ & $-0.138^{* * *}$ & 1.000 & & & & & & & & & \\
\hline (4) Size & $0.128^{* * *}$ & $0.368^{* * *}$ & $-0.358^{* * *}$ & 1.000 & & & & & & & & \\
\hline (5) Age & -0.033 & -0.008 & $-0.104^{* * *}$ & $0.162^{* * *}$ & 1.000 & & & & & & & \\
\hline (6) Growth & $0.193^{* * *}$ & $0.131^{* * *}$ & -0.021 & -0.029 & $-0.060^{* * *}$ & 1.000 & & & & & & \\
\hline (7) Top & $0.083^{* * *}$ & $0.230^{* * *}$ & -0.008 & $0.159^{* * * *}$ & $-0.082^{* * *}$ & $-0.091^{* * *}$ & 1.000 & & & & & \\
\hline (8) Owner & $-0.146^{* * *}$ & $0.142^{* * *}$ & $-0.176^{* * *}$ & $0.296^{* * *}$ & $0.157^{* * *}$ & $-0.105^{* * *}$ & $0.111^{* * *}$ & 1.000 & & & & \\
\hline (9) Dual & $0.081^{* * *}$ & $-0.021^{* * *}$ & $0.117^{* * *}$ & $-0.052^{* * *}$ & -0.051 & -0.015 & -0.002 & $-0.292^{* * *}$ & 1.000 & & & \\
\hline (10) Dsize & $0.008^{* * *}$ & $0.082^{* * *}$ & $-0.109^{* * *}$ & $0.190^{* * *}$ & $0.081^{* * *}$ & -0.021 & $-0.084^{* * *}$ & $0.245^{* * *}$ & $-0.264^{* * *}$ & 1.000 & & \\
\hline (11) Monisize & 0.011 & $0.104^{* * *}$ & $-0.108^{* * *}$ & $0.246^{* * *}$ & $0.084^{* * *}$ & $-0.056^{* *}$ & $0.065^{* * *}$ & $0.458^{* * *}$ & $-0.194^{* * *}$ & $0.211^{* * *}$ & 1.000 & \\
\hline (12) TobinQ & 0.339 & -0.015 & $0.314^{* * *}$ & $-0.359^{* * *}$ & $-0.071^{* * *}$ & $0.147^{* * *}$ & $-0.104^{* * *}$ & $-0.250^{* * *}$ & $0.091^{* * *}$ & $-0.171^{* * *}$ & $-0.123^{* * *}$ & 1.000 \\
\hline (13)mean & 6.381 & 0.404 & 0.903 & 7.923 & 18.479 & 16.398 & 33.588 & 0.323 & 0.289 & 8.622 & 3.573 & 2.198 \\
\hline
\end{tabular}

Note. ${ }^{*}, * *$, and ${ }^{* * *}$ denote significances at the $10 \%, 5 \%$, and $1 \%$ levels, respectively. 
Table 4. Regression results

\begin{tabular}{|c|c|c|c|}
\hline Variables & $\begin{array}{c}(1) \\
\text { ROA }\end{array}$ & $\begin{array}{l}(2) \\
\mathrm{DC} \\
\end{array}$ & $\begin{array}{c}(3) \\
\text { ROA } \\
\end{array}$ \\
\hline DC & & & $\begin{array}{c}14.7421^{* * *} \\
(1.5991)\end{array}$ \\
\hline $\mathrm{FF}$ & $\begin{array}{l}.7074^{* * *} \\
(1.1479)\end{array}$ & $\begin{array}{l}.0051^{* *} \\
(.0210)\end{array}$ & $\begin{array}{l}.5997^{* * *} \\
(1.1036)\end{array}$ \\
\hline FF2 & $\begin{array}{l}-.1124^{* * *} \\
(2.4388)\end{array}$ & $\begin{array}{c}-.0024^{* * *} \\
(.04620)\end{array}$ & $\begin{array}{c}-.0675^{* * *} \\
(2.4160)\end{array}$ \\
\hline Size & $\begin{array}{c}1.6507^{* * *} \\
(.1079)\end{array}$ & $\begin{array}{c}.0367^{* * *} \\
(.0027)\end{array}$ & $\begin{array}{c}1.1156^{* * *} \\
(.1276)\end{array}$ \\
\hline Age & $\begin{array}{c}.0022 \\
(.0144)\end{array}$ & $\begin{array}{l}-.0002 \\
(.0002)\end{array}$ & $\begin{array}{c}.0039 \\
(.0123)\end{array}$ \\
\hline Growth & $\begin{array}{c}.02706^{* * *} \\
(.0047)\end{array}$ & $\begin{array}{c}.00055^{* * *} \\
(.0001)\end{array}$ & $\begin{array}{c}.01721^{* * *} \\
(.0043)\end{array}$ \\
\hline Top & $\begin{array}{l}.0292^{* * *} \\
(.0084)\end{array}$ & $\begin{array}{l}.0011^{* * *} \\
(.0001)\end{array}$ & $\begin{array}{c}.0099^{* * *} \\
(.0080)\end{array}$ \\
\hline Owner & $\begin{array}{c}-1.2626^{* * *} \\
(.2328)\end{array}$ & $\begin{array}{l}.0168^{* * *} \\
(.0057)\end{array}$ & $\begin{array}{c}-1.5221^{* * *} \\
(.2274)\end{array}$ \\
\hline Dual & $\begin{array}{c}.3608 \\
(.2365)\end{array}$ & $\begin{array}{c}.0023 \\
(.0043)\end{array}$ & $\begin{array}{c}.2327 \\
(.2141)\end{array}$ \\
\hline Dsize & $\begin{array}{l}.1841^{* *} \\
(.0788)\end{array}$ & $\begin{array}{c}.0012 \\
(.0015)\end{array}$ & $\begin{array}{l}.1520^{* *} \\
(.0736)\end{array}$ \\
\hline Monisize & $\begin{array}{l}.2056^{*} \\
(.1046)\end{array}$ & $\begin{array}{l}-.0021 \\
(.0023)\end{array}$ & $\begin{array}{l}.2390^{* *} \\
(.0941)\end{array}$ \\
\hline TobinQ & $\begin{array}{c}1.3666^{* * *} \\
(.1002)\end{array}$ & $\begin{array}{l}.0141^{* * *} \\
(.0016)\end{array}$ & $\begin{array}{c}1.1884^{* * *} \\
(.0935)\end{array}$ \\
\hline Year & yes & yes & yes \\
\hline Constant & $\begin{array}{c}-12.3218^{* * *} \\
(1.1923)\end{array}$ & $\begin{array}{l}.0512^{*} \\
(.0263)\end{array}$ & $\begin{array}{c}-12.8457^{* * *} \\
(1.1053)\end{array}$ \\
\hline $\begin{array}{c}\text { F-test(joint } \\
\text { significance) }\end{array}$ & $\begin{array}{l}F=36.77 \\
P=0.000\end{array}$ & $\begin{array}{l}F=39.23 \\
P=0.000\end{array}$ & $\begin{array}{l}F=43.74 \\
P=0.000\end{array}$ \\
\hline $\mathrm{N}$ & 292 & 292 & 292 \\
\hline $\mathrm{R}^{2}$ & 0.3016 & 0.2892 & 0.3636 \\
\hline Adj- $R^{2}$ & 0.2941 & 0.2816 & 0.3562 \\
\hline
\end{tabular}

Note. ${ }^{*},{ }^{* *}$, and ${ }^{* * *}$ denote significances at the $10 \%, 5 \%$, and $1 \%$ levels, respectively, with p-values in parentheses.

\subsection{Estimation results}

Table 4 shows the results of the regression test. Estimated regression coefficients for Eq.(1) are shown in columns (1). It appears that the coefficients of FF and FF2 are 0.707401 and -0.112375 , which are both significantly positive at the $1 \%$ level. At the same time, the $F$ test rejects the null hypothesis that the primary and square terms of financial flexibility are zero at the $1 \%$ level. The coefficient of FF2(-0.112375) is negative, according to the characteristics of the quadratic curve, it is inferred that the curve is with an opening downward. It reveals that the effect of financial flexibility on enterprise performance has a range effect. Estimated regression coefficients for Eq.(2) are shown in column (2). It appears that the coefficient of financial flexibility is 0.005059 , which is significantly positive at the $5 \%$ level, and the coefficient of financial flexibility squared is -0.002381 , which is significantly negative at the $1 \%$ level. Also, the $\mathrm{F}$ test rejects the null hypothesis in that the primary and square terms of financial flexibility are zero at the $1 \%$ level. The coefficient of FF2(-0.002381) is negative, which also supports the hypothesis that financial flexibility and dynamic capabilities are inverted U-shaped. Estimated 
regression coefficients for Eq. (3) are shown in column (3). It appears that the coefficient of dynamic capability is 14.74212 , and the coefficients of FF and FF2 are 0.599674 and -0.067451 , which are all significantly positive at the level of $1 \%$. Also, the $\mathrm{F}$ test rejects the null hypothesis that the primary and square terms of financial flexibility are zero at the $1 \%$ level, indicating that the dynamic capability partially plays an intermediary role.

\section{Conclusions and implications}

Based on manufacturing listed enterprises in Shanghai and Shenzhen Securities Markets in China from 2011 to 2017, this article analyzes the impact of financial flexibility on enterprise performance and its mechanism from the perspective of dynamic capabilities. Through demonstrating the positive and negative impact of financial flexibility on enterprise performance, this article verifies the inverted $\mathrm{U}$ shaped relationship between financial flexibility and enterprise performance of listed companies in Chinese manufacturing and further confirms this view with robustness tests. The conclusion of this article generalizes the previous viewpoints and makes it clearer, compared to previous researchers (KUSNADI, 2011; ArslanAyaydin et al., 2014). The article also discusses the relationship between financial flexibility and dynamic capabilities. From the angle of definition, it analyzes the internal relationship between the two variables and points out the specific characteristics of enterprise financial flexibility and dynamic ability in a low dynamic and high dynamic environment where the hypothesis that financial flexibility and dynamic ability are inverse U-shaped is proposed. The empirical results show that the inverse U-shaped relationship between financial flexibility and dynamic capabilities is established, and the robustness test also supports the above viewpoint. Few scholars have studied this before. Therefore, this article incorporates dynamic capabilities into the mechanism of financial flexibility on enterprise performance finally. The empirical results show that dynamic capabilities can positively affect enterprise performance, which has already been proved by many researchers before (Makadok, 2001; Zollo, 2002; Drnevich \& Kriauciunas, 2011). It further supports that dynamic capabilities play a partial intermediary role in the impact of financial flexibility on enterprise performance. This provides a new way of exploring the mechanism of the impact of financial flexibility on enterprise performance.

This article discusses the relationship between two important variables of financial flexibility and dynamic capability and enterprise performance and provides important inspiration for the financial management of Chinese manufacturing enterprises facing transformation and modernization. The unstable external market coupled with fund management issues that are ubiquitous has made Chinese manufacturing enterprises cautious in making financial decisions. For financial flexibility, which is an important influencing factor, enterprises should avoid not only insufficient investment and financing difficulties caused by low financial flexibility but also the agency cost problem caused by strong financial flexibility. These problems may result in inefficient investment and unnecessary waste. From the perspective of dynamic capabilities, enterprises maintain financial flexibility at a reasonable and moderate level after weighing the cost of carrying and potential benefits so that the dynamic capabilities of enterprises try their best to improve the enterprise performance. This article suggests manufacturing enterprises should fully consider the impact on the market, technology, organizational behavior and other aspects of financial resources when deploying and applying financial resources, which is conducive to the company to make correct management decisions.

Funding: This research was funded by the National Natural Science Foundation of China, grant number 19FGLB038.

Conflicts of Interest: The authors declare no conflict of interest. The funders had no role in the design of the study; in the collection, analyses, or interpretation of data; in the writing of the manuscript, or in the decision to publish the results 


\section{Appendix}

To ensure the reliability of the research conclusions, this paper uses the Return on Capital (ROC) as a surrogate index to measure enterprise performance and the regression results of the robustness test are shown in Table 5. This article sets

ROC $=$ (net profit + financial expenses) $/$ (total assets - current liabilities + notes payable + shortterm loans + non-current liabilities due within one year).

The results of column $(1)$ of show that the coefficient of financial flexibility $(\beta=0.006584, \mathrm{P}<0.01)$ and financial flexibility squared $(\beta=-0.0012039, P<0.01)$ are significantly positive and negative, respectively. $\mathrm{F}$ test rejects the null hypothesis that both primary and squared terms of financial flexibility are zero at the $1 \%$ level. Considering that -0.0012039 is under 0 and the characteristics of curve, it can be inferred that financial flexibility has an inverted u-shaped relationship with ROC, which further supports hypothesis H1. Column (2) shows the regression results with the addition of dynamic capabilities. The coefficient $(\beta=0.168822, \mathrm{P}<0.01)$ of the dynamic capability and financial flexibility $(\beta=0.005409, P<0.01)$ are significantly positive, what's more, the coefficient of financial flexibility squared $(\beta=-0.000723, \mathrm{P}<0.01)$ is also significantly negative. $\mathrm{F}$ test rejects the null hypothesis that the primary and secondary terms of financial flexibility are both zero at the level of $1 \%$, indicating that $\mathrm{H} 3$ also passes the robustness test, namely, the hypothesis that dynamic capability plays an incomplete intermediary role in financial flexibility's enterprise performance effect is established.

Table 5. Robustness test results

\begin{tabular}{|c|c|c|}
\hline Variables & $\begin{array}{c}(1) \\
\text { ROC }\end{array}$ & $\begin{array}{c}\text { (2) } \\
\text { ROC }\end{array}$ \\
\hline $\mathrm{DC}$ & & $\begin{array}{l}.1688^{* * *} \\
(.0174)\end{array}$ \\
\hline FF & $\begin{array}{l}.0066^{* * *} \\
(.0122)\end{array}$ & $\begin{array}{c}.0541^{* * *} \\
(.0118)\end{array}$ \\
\hline FF2 & $\begin{array}{c}-.0012^{* * *} \\
(.0279)\end{array}$ & $\begin{array}{c}-.0723^{* * *} \\
(.0246)\end{array}$ \\
\hline Size & $\begin{array}{l}.0197^{* * *} \\
(.0012)\end{array}$ & $\begin{array}{c}.0137^{* * *} \\
(.0015)\end{array}$ \\
\hline Age & $\begin{array}{c}.00002 \\
(.00013)\end{array}$ & $\begin{array}{c}.00005 \\
(.00012)\end{array}$ \\
\hline Growth & $\begin{array}{l}.0003^{* * *} \\
(.0001)\end{array}$ & $\begin{array}{l}.0002^{* * *} \\
(.0001)\end{array}$ \\
\hline Owner & $\begin{array}{c}-.0104^{* * *} \\
(.0028)\end{array}$ & $\begin{array}{c}-.0133^{* * * *} \\
(.0025)\end{array}$ \\
\hline Top & $\begin{array}{l}.0003^{* * *} \\
(.0001)\end{array}$ & $\begin{array}{c}.0001 \\
(.0001)\end{array}$ \\
\hline Dual & $\begin{array}{l}.0070^{* * * *} \\
(.0025)\end{array}$ & $\begin{array}{l}.0057^{* *} \\
(.0023)\end{array}$ \\
\hline Dsize & $\begin{array}{l}.0025^{* * *} \\
(.0008)\end{array}$ & $\begin{array}{l}.0022^{* * *} \\
.0008)\end{array}$ \\
\hline Monisize & $\begin{array}{c}.0010 \\
(.0012)\end{array}$ & $\begin{array}{c}.0013 \\
(.0011)\end{array}$ \\
\hline TobinQ & $\begin{array}{c}.014432^{* * *} \\
(.0010)\end{array}$ & $\begin{array}{l}.0125^{* * *} \\
(.0010)\end{array}$ \\
\hline Year & yes & yes \\
\hline Constant & $\begin{array}{c}-.1495^{* * *} \\
(.01205)\end{array}$ & $\begin{array}{c}-.1571^{* * *} \\
(.01242)\end{array}$ \\
\hline F-test(joint significance) & $\begin{array}{c}\mathrm{F}=39.373 \\
\mathrm{P}=0.000\end{array}$ & $\begin{array}{l}F=42.55 \\
P=0.000\end{array}$ \\
\hline $\mathrm{N}$ & 292 & 292 \\
\hline $\mathrm{R}^{2}$ & 0.3142 & 0.3822 \\
\hline Adj-R ${ }^{2}$ & 0.3068 & 0.3751 \\
\hline
\end{tabular}

Note. ${ }^{*},{ }^{* *}$, and ${ }^{* * *}$ denote significances at the $10 \%, 5 \%$, and $1 \%$ levels, respectively, with $p$-values in parentheses. 


\section{References}

Agha, M., \& Faff, R. (2014). An investigation of the asymmetric link between credit re-ratings and corporate financial decisions: "Flicking the switch" with financial flexibility. Journal of Corporate Finance, 29(2), 37-57. https://doi.org/10.1016/j.jcorpfin.2014.08.003

Arbogast, S., \& Kumar, P. (2018). Financial flexibility and opportunity capture: Bridging the gap between finance and strategy. Journal of Applied Corporate Finance, 30(1), 23-29. DOI: 10.1111/jacf.12274

Baron, R.-M. \& Kenny, D.-A. (1986). The moderator-mediator variable distinction in social psychological research: Conceptual, strategic, and statistical considerations. Journal of Personality and Social Psychology, 51, 1173-1182. DOI: $10.1037 / 0022-3514.51 .6 .1173$

Barreto, I. (2010). Dynamic Capabilities: A review of past research and an agenda for the future. Journal of Management, 36(1), 256-280. https://doi.org/10.1177/0149206309350776

Byoun, S. (2011). Financial flexibility and capital structure decision. Baylor University Working paper.

Cherkasova, V., Kuzmin, E., \& Gadjah, M. (2018). Financial Flexibility as an Investment Efficiency Factor in Asian Companies. International Journal of Business, 20(2), 137-164. https://doi.org/10.22146/gamaijb.26239

Dong, L., \& MAO, N. (2016). Excess cash holding, managerial discretion and investment distortion -the effect of spare liability capacity from the perspective of financial flexibility theory. Modern Economic Science, 38(2), 94-102.

Drnevich, P.-L. \& Kriauciunas, A.-P. (2011). Clarifying the conditions and limits of the contributions of ordinary and dynamic capabilities to relative enterprise performance. Strategic Management Journal, 32(3), 254-279. DOI: https://doi.org/10.1002/smj.882

Eisenhardt, K.-M. \& Martin, J.-A. (2000). Dynamic capabilities: what are they? Strategic Management Journal, 21(10/11), 1105-1121. https://doi.org/10.1002/1097-0266(200010/11)21:10/11<1105:: AID-

Fainshmidt, S., Wenger, L., Pezeshkan, A., \&Mallon M R. (2019). When do dynamic capabilities lead to competitive advantage? the importance of strategic fit. Journal of Management Studies, 56(4), 758-787. https://doi.org/10.1111/joms.12415

García, N.-N. (2010). Dynamic capabilities understanding strategic change in organizations / Constance E. Helfat [et.al]. Malden: Blackwell Publishing, 2007. (69).

Gilson, S.-C., \& Warner, J.-B. (1998). Private versus public debt: evidence from firms that replace bank loans with junk bonds. Social Science Electronic Publishing.

Graham, J.-R., \& Harvey, C.-R. (2001). The theory and practice of corporate finance: evidence from the field. Journal of Financial Economics, 60(2-3), 187-243. https://doi.org/10.1016/S0304-405X(01)00044-7

Griffith, D.-A. \& Harvey, M.-G. (2001). A resource perspective of global dynamic capabilities. Journal of International Business Studies, 32(3), 597-606. https://doi.org/10.1057/palgrave.jibs.8490987

Hart, O., \& Moore, J. (1998). Default and renegotiation: A dynamic model of debt. Social Science Electronic Publishing, 113(1), 1-41. https://doi.org/10.1162/003355398555496

Hayward, M., Caldwell, A., Steen, J., Gow, D., \& Liesch, P. (2017). Entrepreneurs' capital budgeting orientations and innovation outputs: Evidence from Australian biotechnology firms. Long Range Planning, 50(1), 121-133. https://doi.org/10.1016/j.lrp.2016.06.002

Jensen, M.-C. (1986). Agency costs of free cash flow, corporate finance, and takeovers. American Economic Review, 76(2), 323-329. https://doi.org/10.2139/ssrn.99580

Jose, I., \& Angel Zuniga-Vicente, Jose. (2003). Resources and strategic change in an unstable industry: the case of aSpanish private barking. European Business Journal, (2), 79-93.

Karim, S. (2006). Modularity in organizational structure: the reconfiguration of internally developed and acquired business units. Strategic Management Journal, 27(9), 799-823. https://doi.org/10.1002/smj.547

Kusnadi, Y. (2011). Do corporate governance mechanisms matter for cash holdings and firm value? Pacific-Basin Finance Journal,19(5), 554-570. https://doi.org/10.1016/j.pacfin.2011.04.002

Makadok, R. (2001). Toward a synthesis of the resource-based and dynamic-capability views of rent creation. Strategic Management Journal, 22(5), 387-401. https://doi.org/10.1002/smj.158

Özgür, ArslanAyaydin., Florackis, C., \& Ozkan, A.(2014). Financial flexibility, corporate investment and performance: evidence from financial crises. Review of Quantitative Finance \& Accounting, 42(2), 211-250. https://doi.org/10.1007/s11156-012-0340-x

Pavlou, P.-A. \& Sawy, O. A.-E. (2011). Understanding the elusive black box of dynamic capabilities. Decision Sciences, 42(1), 239-273. https://doi.org/10.1111/j.1540-5915.2010.00287.x 
Rapp, M.-S., Schmid, T., \& Urban, D. (2014). The value of financial flexibility and corporate financial policy. Journal of Corporate Finance, 29, 288-302. https://doi.org/10.1016/j.jcorpfin.2014.08.004

SMJ133>3.0.CO;2-E

Teece, D.-J. \& Pisano, G. (1994). The dynamic capabilities of firms: An introduction. Industrial and Corporate Change, 3(3). https://doi.org/10.1093/icc/3.3.537-a

Teece, D.-J. \& Pisano, G. (1997). Schuen A. Dynamic capabilities and strategic management. Strategic Management Journal, 18(5), 509-533.

Teece, D.-J. (2007). Explicating dynamic capabilities: the nature and microfoundations of (sustainable) enterprise performance. Strategic Management Journal, 28(13), 1319-1350.

Teece, D.-J. (2012). Dynamic Capabilities: Routines versus entrepreneurial action. Journal of Management Studies, 49(8), 1395-1401. https://doi.org/10.1111/j.1467-6486.2012.01080.x

Wang A.-Q. \& Tang W. -P. (2017). Impact of environmental uncertainty on the relationship between financial flexibility and enterprise growth. China Soft Science, (3), 186-192.

Wang, C.-L. \& Ahmed, P.-K. (2010). Dynamic capabilities: A review and research agenda. International Journal of Management Reviews, 9(1), 31-51. https://doi.org/10.1111/j.1468-2370.2007.00201.x

Wilhelm, H., Schlömer, M., \& Maurer, I. (2015). How dynamic capabilities affect the effectiveness and efficiency of operating routines under high and low levels of environmental dynamism. British Journal of Management, 26(2), 327-345. https://doi.org/10.1111/1467-8551.12085

$\mathrm{Wu}, \mathrm{L} .-\mathrm{Y}$. (2006). Resources, dynamic capabilities and performance in a dynamic environment: Perceptions in Taiwanese IT enterprises. Information and Management, 43(4), 447-454. https://doi.org/10.1016/j.im.2005.11.001

Yang, L. \& Pan, Z. (2019). Dynamic Relationship Between Financial Flexibility and Performance - Moderating Effect of Financing Constraint and Agency Cost. Research on Economics and Management, 40(04), 125-144.

Zahra, S.-A., Sapienza, H.-J., \& Davidsson, P. (2010). Entrepreneurship and dynamic capabilities: A review, model and research agenda. Journal of Management Studies, 43(4), 917-955. https://doi.org/10.1111/j.14676486.2006.00616.x

Zeng, A., Zhang, C., \& Wei, Z.H. (2013). The Impact of Financial Crisis, Financial Flexible Reserves and Corporate Investment Behavior: Empirical Evidence from Chinese Listed Companies . Management World, (4), 107-120.

Zollo, M., \& Winter, S.-G. (2002). Deliberate learning and the evolution of dynamic capabilities. Organization Science, 13(3), 339-351. https://doi.org/10.1287/orsc.13.3.339.2780

(C) 2020 by the authors. This article is an open-access article distributed under the terms and conditions of the Creative Commons Attribution (CC BY) license (http://creativecommons.org/licenses/by/4.0/). 